\title{
Validation of annual growth increments in the otoliths of a small, tropical coral reef fish
}

\author{
Anthony J. Fowler \\ Australian Institute of Marine Science, PMB No. 3, Townsville M. C., Queensland 4810, Australia
}

\begin{abstract}
Three criteria were assessed to determine the usefulness of otoliths to age individuals of Pomacentrus mollucensis collected from the lagoon of John Brewer Reef on the central Great Barrier Reef between March 1988 and February 1989. (1) Otoliths, as measured along various axes, demonstrated asymmetrical growth through time, but nevertheless grew throughout the lives of the fish. (2) A total of 18 fish recaptured after treatment with tetracycline 1 yr previously, demonstrated one thin, opaque increment in the otolith structure that had formed since treatment. (3) Marginal increment analysis, while not as definitive, strongly suggested that opaque increments were formed in the austral spring, generally between September and November These 3 results indicated that opaque increments found in the otoliths of $P$. mollucensis are formed annually and hence can be used to determine agespecific parameters of the populations. Von Bertalanffy growth curves and age structures were derived for 3 representative samples to illustrate this point.
\end{abstract}

\section{INTRODUCTION}

There are 3 techniques for providing information on the age and growth of fishes: length frequency analysis, tag-recapture studies and direct aging from the hard anatomical structures (Jones 1976, Ricker 1979). Of these, the latter is the preferred method as it is least prone to subjective interpretation and tagging artefacts (Brothers 1982). In temperate regions, fisheries management largely relies upon this technique for aging, and the otoliths have emerged as the most-often preferred anatomical structure (Bagenal 1974, Manooch 1982, Pentilla \& Dery 1988).

Direct aging of tropical fishes has not enjoyed the same success as that experienced in temperate regions (Panella 1980, Longhurst \& Pauly 1987). This has been attributed to a lack of a discernible or interpretable pattern in structures such as the otoliths, which has been related to equitable growth in the supposed aseasonal environment of the tropics (Pannella 1980, reviewed in Brothers 1982). Yet, some observations for the families Lutjanidae, Serranidae, Lethrinidae and Sciaenidae (Poinsard \& Troadec 1966, Loubens 1978, Johnson 1983, Manooch 1987, McPherson et al. 1988) have indicated that annuli may occur more generally in tropical taxa than was previously thought (Longhurst \& Pauly 1987).
Research into the ecology of the small, demersal fish associated with tropical and subtropical coral reefs has been essentially devoid of age-based demographic work. The purpose of this work, therefore, was to assess the applicability of direct aging for one such fish from the Great Barrier Reef (GBR) of Australia. The species, Pomacentrus mollucensis, is a small coral reef fish that occupies restricted home ranges and is strongly associated with live branching coral. The specific aims of this research were to assess the 3 criteria that otoliths must fulfill in order to be useful for aging purposes: (1) that otoliths continue to grow through the lives of the fish; (2) that otoliths display visible growth increments; (3) that such increments are formed on a regular, determinable time scale. The final aim of the work was to describe several populations of $P$. mollucensis in terms of age-specific parameters such as growth patterns and age structures.

\section{MATERIALS AND METHODS}

Fish collection and treatment. Specimens were collected from large micro-atolls in the lagoon of John Brewer Reef $\left(18^{\circ} 38^{\prime} \mathrm{S}, 147^{\circ} 04^{\prime} \mathrm{E}\right)$, located $70 \mathrm{~km}$ from Townsville on the central GBR of Australia (Fig. 1). On 16 March 1988, 21 specimens of Pomacentrus mol- 


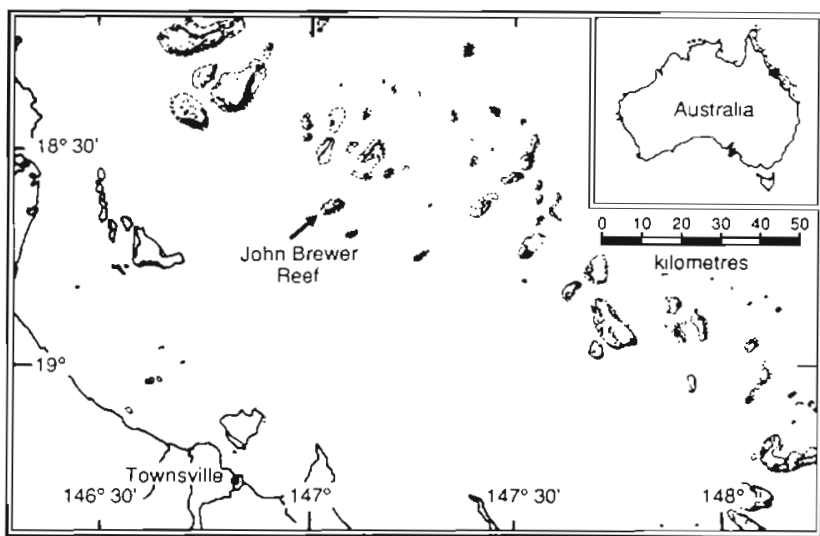

Fig. 1. Central region of the Great Barrier Reef showing the location of John Brewer Reef

lucensis were captured using small hand spears. This method was selective and biased the sample towards large individuals. Consequently, subsequent collecting was done by clearing fish from coral heads using the fish anaesthetic Quinaldine and small hand nets. With several divers concentrating on individual coral heads complete collection of isolated populations were made. By so doing, 57 fish were collected on 3 September 1988,45 on 3 to 4 November 1988 and 59 on 26 to 27 February 1989. Fish were preserved in $80 \%$ ethanol and dissected for the removal of otoliths soon after the field trip, in order to minimise the exposure of the otoliths to the preserving solution. Prior to dissection, fish were weighed (preserved weight in $\mathrm{mg}$ ) and measured (standard length in $\mathrm{mm}$ ). After dissection, otoliths were cleaned, washed in distilled water and stored dry in numbered glass vials. All analyses were done on the sagittae, the largest pair of otoliths.

Analysis of otoliths. Whole otoliths: Sagittae were weighed (to $10^{-2} \mathrm{mg}$ ) and measured along 3 axes (Fig. 2a) using a dissecting microscope and an ocular micrometer (25× magnification). These axes were: total length $\left(\mathrm{OL}_{1}\right)$, a second measure of length $\left(\mathrm{OL}_{2}\right)$ - the distance from the base of the dense, opaque region to the tip of the otolith - , and otolith breadth (OB). All measurements were made as close as possible through the otolith core. The size of each sagitta (length and weight) was related to the size of the fish (length and weight) using linear regression. When data had heterogeneous variances or when relationships were initially curvilinear, either the dependent or independent variables were transformed using $\ln _{e}(x+1)$.

Tranverse sections: Recently a cautious approach has been recommended for the interpretation of whole otoliths, as this technique has under-estimated the age of fish compared with sections of otoliths (Power 1978, Beamish 1979a, b, Campana 1984, Fujiwara \& Hankin 1988). To avoid the potential under-estimation of age a

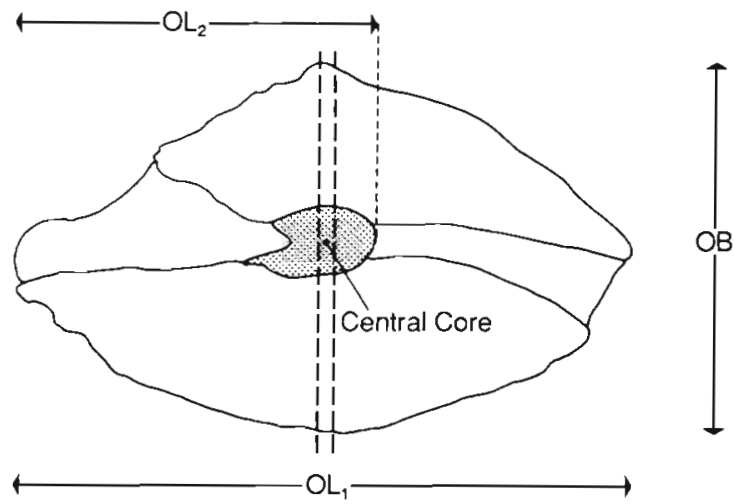

b

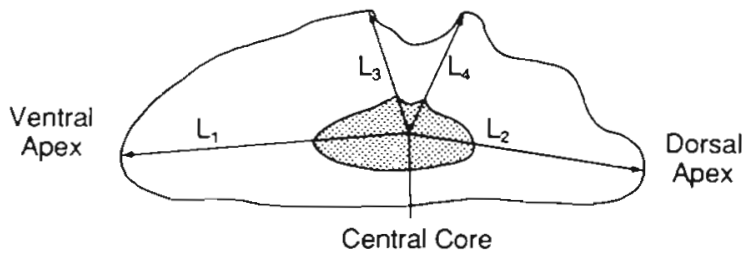

Fig. 2. Pomacentrus mollucensis. (a) Whole otolith. (b) Transverse section. Schematic diagrams showing axes along which the various measurements were made. Central, dense opaque regions are stippled, broad dashed lines in whole otolith indicate preferred area for TS section incorporating the central core

from whole otoliths all aging work here was based on the analysis of tranverse sections of the otoliths.

One sagitta from each fish was ground and polished to produce a thin section incorporating the central core or as close as was possible. This was done by haphazardly selecting one sagitta per fish and embedding this in Spurr's histological resin to form a small rectangular block. One face of this block was ground and polished to a level near the core, perpendicular to the long axis of the otolith. This was done using a gem facetting machine and several grades of ebony paper $(120,1000)$ and lapping film $(9,3,1 \mu \mathrm{m})$. This polished surface was glued to a microscope slide with Spurr's resin, and the block was ground and polished from the opposite direction to produce a polished, thin TS section between 50 to $100 \mu \mathrm{m}$ thick. Sections that retained the central core were measured from this point to each of 4 peripheral points: the ventral apex (L1), the dorsal apex (L2), and the ventral and dorsal sides of the sulcus (L3, L4 respectively) (Fig. 2b).

All sections were examined and measurements were made using a Leitz compound microscope incorporating an Ikegami high resolution, black and white video camera, connected to a Commodore Amiga personal computer with a high resolution colour monitor. With 
the image of the otolith displayed on the monitor, the increments were counted and measured along the L1 and L3 axes indicated in Fig. 2b.

Validation of period of increment formation. The rate at which increments were formed in the otoliths was assessed using 2 techniques: (1) marking otoliths in situ with tetracycline, and (2) attempting to determine when increments were formed by measuring marginal increments.

Treatment with tetracycline: When fish are treated with tetracycline, it is metabolised and deposited in their bony tissues for a short time, ultimately forming a time-marker in the various calcareous structures, including otoliths (Kobayashi et al. 1964, Odense \& Logan 1974). On 26 to 27 March 1988, fish were collected from isolated colonies of the hard coral Pocillopora damicornis using Quinaldine, injected with a volume of tetracycline solution determined by their size, and released into the coral head from which they had been captured. Injection was done with a $1.0 \mathrm{~mm}$ syringe and a 26 gauge needle $(0.45 \times 13 \mathrm{~mm})$ which was inserted through the skin, under the mid-lateral, post-pectoral scales into the coelomic cavity. Fish were treated with tetracycline equivalent to $50 \mathrm{mg} \mathrm{kg}^{-1}$ body weight (McFarlane \& Beamish 1987). Since weight of the captured specimens could not be determined in the field, the relationship between body weight and SL was initially determined for a sample of 21 fish whose fresh weight and size were measured within an hour of capture. From this relationship, the volumes of the solution ( $5.0 \mathrm{mg}$ tetracycline per $\mathrm{ml}$ of sterile saline) to be administered were determined from the SL.

On 3 September 1988, 24 fish were removed from these coral heads and a further 59 were collected on 26 to 27 February 1989. Both samples were preserved and dissected according to the procedures described above, after which the whole otoliths and, later, the sections of otoliths were stored in the dark. Sections were examined on 2 occasions using a compound microscope and white incident light, and the opaque increments were counted, and increment distances measured. Later, the otoliths were examined using a compound microscope and incident fluorescent light in a darkened room. When a tetracycline band was evident, this was used to determine the absolute growth of the otolith between treatment and capture, by measuring the distance from this to the edge of the otolith along both the L1 and L3 axes (400x magnification). By comparing measurements made under fluorescent illumination with those made independently under white light, the period of increment formation was determined.

Analysis of marginal increments: If increments in otoliths are formed regularly, and at approximately the same time of year for different age classes, then sam- ples collected at different times of the year should show opaque increments at different distances from the otolith edge. This was investigated by measuring the distance of the last opaque increment from the otolith edge in all tranverse sections and comparing these values amongst samples collected on the 4 different occasions. The sectioned otoliths from all 4 samples were examined in random order, without reference to their date of collection or to previous counts, when the distance between the last increment and the otolith edge was measured along the L1 and L3 axes (Fig. 2b). One-factor analyses of variance were used to compare the marginal increment widths amongst sampling occasions for those age classes with sufficiently large sample sizes. Prior to analysis, data were tested for homogeneity of variances using Cochran's test, and after analyses SNK tests were used to isolate differences amongst means.

Growth and age-structures. Before counts of increments in otoliths can be interpreted in terms of age, it is necessary to consider the confidence that can be placed in the interpretation of the otolith structure. For this, the precision of the counts of the tranverse sections of 124 otoliths was assessed. Each otolith was examined on 2 occasions and the counts were compared between these. Finally, estimates of age were interpreted in terms of growth and age structures. Von Bertalanffy growth curves were fitted to estimates of size-at-age using FISHPARM, a software package for fisheries applications.

\section{RESULTS}

\section{Analysis of otoliths \\ Whole otoliths}

The size of whole otoliths of Pomacentrus mollucensis increased with increasing size of the fish, some relationships being linear whilst others were more complex (Table 1, Fig. 3). Two indices of otolith length $\left(\mathrm{OL}_{1}, \mathrm{OL}_{2}\right)$ were proportional to $\mathrm{SL}$ and these linear relationships each accounted for ca $95 \%$ of the variation in otolith size (Table 1, Fig. 3a). Alternatively, otolith breadth (OB) and SL had a curvilinear relationship with a decreasing slope (Table 1, Fig. 3b), indicating a slowing of the growth rate of the otolith relative to that of the fish. The weight of the sagittae increased exponentially with SL, but decreased with increasing fish weight (Table 1).

Transverse sections

Otolith growth rate along the L1 and L2 axes of the transverse sections decreased relative to SL (Table 1, 
Table 1. Pomacentrus mollucensis. Comparison between sizes of otoliths and sizes of fish. Codes for the parameters of otolith size are from Fig. 2. Wt: weight; OWt: otolith weight; FWt: fish weight. Initial relationship refers to the nature of the relationship between otolith and fish size prior to any transformation, and +ve and -ve refer to the exponents of the curved relationships. For regression analyses, fish size was used as the dependent variable and transformation refers to whether this or the independent variable was transformed $\ln _{e}(x+1)$ prior to the analysis. All regressions were significant at $p<0.001$.

\begin{tabular}{|c|c|c|c|c|c|c|}
\hline $\begin{array}{c}\text { Otolith } \\
\text { dimension }\end{array}$ & $\begin{array}{c}\text { Fish } \\
\text { dimension }\end{array}$ & $\begin{array}{c}\text { Initial } \\
\text { relationship }\end{array}$ & Transformation & $\begin{array}{l}\text { Sample } \\
\text { size }\end{array}$ & Equation & $I^{2}$ \\
\hline $\mathrm{OL}_{1}$ & SL & Linear & Dependent & 169 & $\ln _{e}\left(\mathrm{OL}_{1}+1\right)=0.022 \mathrm{SL}+0.023$ & 0.95 \\
\hline $\mathrm{OL}_{2}$ & SL & Linear & No & 79 & $\mathrm{OL}_{2}=0.027 \mathrm{SL}+0.417$ & 0.94 \\
\hline $\mathrm{OB}$ & SL & Curved - ve & Independent & 171 & $O B=0.928\left(\ln _{e} S L+1\right)-1.875$ & 0.92 \\
\hline Wt & SL & Curved +ve & Dependent & 123 & $\ln _{e}(\mathrm{OWt}+1)=0.041 \mathrm{SL}-0.312$ & 0.90 \\
\hline Wt & Wt & Curved -ve & Independent & 124 & $O W t=2.251\left(\ln _{e} F W t+1\right)+0.086$ & 0.89 \\
\hline L1 & SL & Curved -ve & Independent & 95 & $\mathrm{~L} 1=0.474\left(\ln _{e} \mathrm{SL}+1\right)-0.893$ & 0.80 \\
\hline $\mathrm{L} 2$ & SL & Curved - ve & Independent & 94 & $\mathrm{~L} 2=0.312\left(\ln _{\mathrm{e}} \mathrm{SL}+1\right)-0.717$ & 0.57 \\
\hline L3 & SL & Linear & Dependent & 96 & $\ln _{\mathrm{e}}(\mathrm{L} 3+1)=0.027 \mathrm{SL}-1.925$ & 0.63 \\
\hline $\mathrm{L} 4$ & SL. & Linear & Dependerit & 94 & $\ln _{\epsilon}(\mathrm{L} 4+1)=0.025 \mathrm{SL}-1.878$ & 0.59 \\
\hline
\end{tabular}
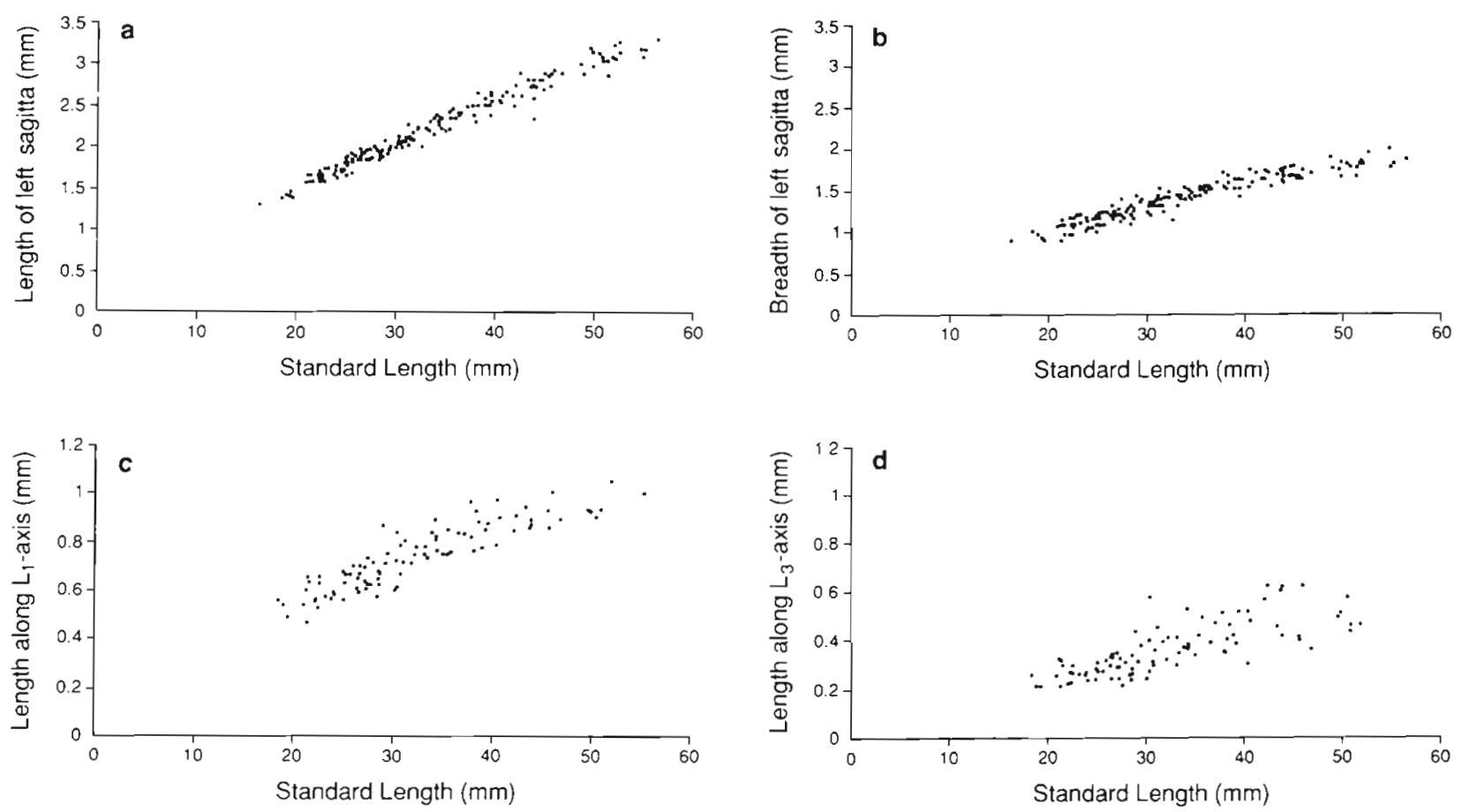

Fig. 3. Pomacentrus mollucensis. (a) Length of left sagitta. (b) Breadth of left sagitta. (c) Length along L1-axis. (d) Length along L3-axis. Relationships between otolith size and fish size ( $\mathrm{mm}$ )

Fig. 3c), reinforcing the result of the decreasing rate of growth of otolith breadth. These accounted for 80 and $57 \%$ of the variation in otolith size respectively. Growth along the L3 and L4 axes of the sagittae was linear but showed increasing variability with increasing SL (Fig. 3d). To make such variances homogeneous the dependent variable was transformed after which SL accounted for ca $60 \%$ of the variability in the otolith measurements. Although the high residual variance can be attributed partly to the differences in shapes of otoliths amongst fish of similar sizes, at least some must also be attributable to the method of preparation of the sections, since it is difficult to obtain polished surfaces perfectly perpendicular to the longitudinal and transverse mid-lines of the otoliths.

When tranverse sections were viewed under reflected light each displayed a central, dense, opaque region (Fig. 4), which was assumed to represent the pre-settlement otolith on the basis of the previouslyreported difference in optical density between pre- and post-settlement regions of otoliths (Victor 1983, Pitcher 1988, Fowler 1989). Surrounding this was a region of 


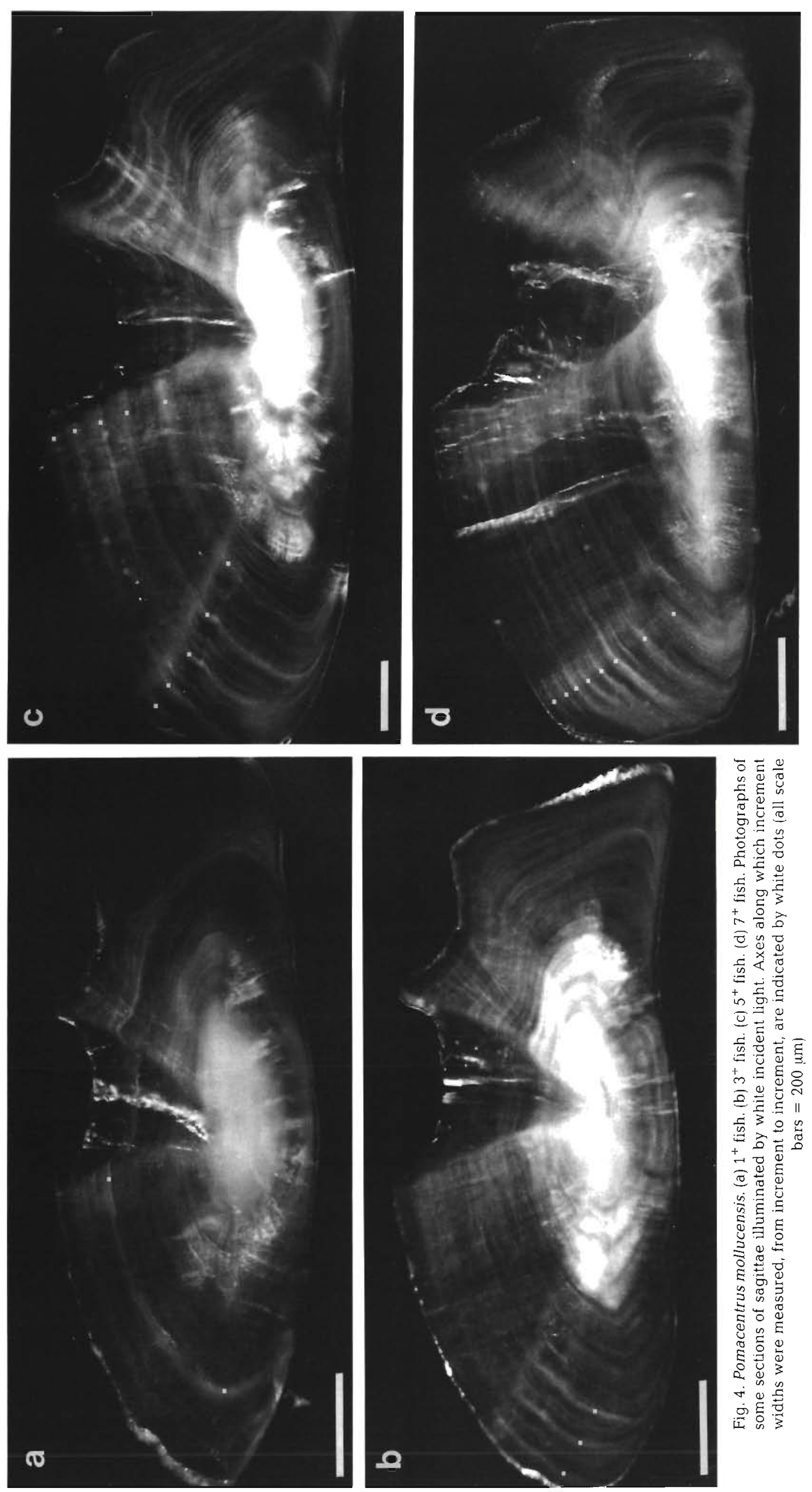


decreasing opacity which eventually became clear. Beyond this point, larger otoliths had alternating sequences of thin opaque increments separated by wider translucent areas. These opaque increments were counted and the distance from the central core measured along the axes indicated in Fig. 4. As is evident in Figs. 4c, d, formation of increments along the L1 axis did not necessarily follow a linear path from the central core, as after the first few increments had been formed, new material was added in layers to the medial surface that did not necessarily extend down to the ventral tip (L1-axis). Here, increments were measured from one to the next, following a curved axis directed towards this medial surface, moving perpendicularly from the inner to the next most outer increment (i.e. the points marked by white dots in Fig, 4).

Otolith sections of 50 to $100 \mu \mathrm{m}$ thickness were the clearest and least ambiguous to interpret using reflected white light. In such sections, opaque increments were thin relative to the clear regions between them and occasionally an increment could be followed from the ventral to the dorsal tips. Generally, however, the clarity of increments was disrupted in the L2 and L4 axes and interpretation was primarily made along the L1 and L3 axes as indicated in Fig. 4.

\section{Validation of the period of increment formation}

\section{Treatment with tetracycline}

Fish were collected from the reef on 2 occasions subsequent to their injection with tetracycline. Five of the 24 fish collected in September 1988, and 18 of 59 collected in February 1989, showed tetracycline in their otoliths (Fig. 5). In these otoliths the tetracycline band appeared as a thin, sharp, distinct, yellow line distinctly more coloured than the white autofluorescence around the edge of the section. Those otoliths that did not display a fluorescent band showed no evidence of yellow fluorescence around the otolith edge, that would otherwise suggest zero otolith growth in a tagged individual. Furthermore, the size range of fish that did display a fluorescent band included some large individuals, whose otoliths showed considerable growth. Consequently, it is likely that the fish whose otoliths did not have an internal fluorescent band had not previously been treated with tetracycline.

The tagged fish that were successfully recaptured had been free-living after treatment for 168 and $335 \mathrm{~d}$ respectively. Fish from the first collection were generally smaller and their otoliths had grown considerably less in the L1 and L3 axes than those collected in February (Fig. 6a, b). Over the longer time period the rate of growth of the otoliths decreased with $\mathrm{SL}$, although there was considerable variation in this rate amongst fish of similar sizes (Figs. 6a, b).

Of the 5 fish collected in September, the 4 smallest ( 22.7 to $30.6 \mathrm{~mm} \mathrm{SL}$ ) had no opaque increments when viewed under reflected, white light (Table 2). The fifth and largest fish (36.5 mm SL) had one opaque increment that was inside (closer to the otolith core than) the tetracycline band. Therefore, in the $168 \mathrm{~d}$ since treatment with tetracycline no fish had formed an opaque increment. The 18 fish collected in February 1989 ranged in size between 30.5 and $55.1 \mathrm{~mm}$ SL and their otoliths varied in size and number of increments, accordingly. Each of these displayed one opaque increment between the tetracycline band and the edge of the otolith (Table 2), as is demonstrated by the 2 otoliths in Fig. 5. Therefore, in each otolith the last opaque increment had formed in the $335 \mathrm{~d}$ since treatment with tetracycline. Since, as indicated above, the fish collected in early September displayed no new opaque increment this suggests that formation of the opaque increment in these latter fish occurred between September and February.

As the opaque increments can now be interpreted as being produced on an annual basis, the growth of the otoliths can be re-analysed in terms of age of the fish at time of capture. This analysis shows that otolith growth slows exponentially with increasing age (Fig. $7 \mathrm{a}, \mathrm{b}$ ), but the residual variability is reduced considerably, relative to that between otolith growth and fish size (Fig. 6a, b).

\section{Analysis of marginal increments}

Increment widths decreased exponentially with increment number as counted away from the otolith core along the L1 and L3 axes (Fig. 8). The comparison of the pattern of change along the 2 different axes provided further evidence of the allometric growth of the otoliths. Growth was initially fastest along the L1 axis, but by the fifth increment, growth was similar in both dimensions. This equality was largely due to the curved path along which the measurements were made in the L1 axis, which was related to the deposition of layers to the medial surface of the otoliths (e.g. Fig. 4d). Approximately equal thickness of material was added to the medial surface, but which did not necessarily extend down to the dorsal and ventral apices of the otolith

The frequency distributions of the marginal increments from fish collected at different times of the year for each age class generally had the highest median in September, lowest in November and intermediate in February-March (Fig. 9). One exception here was the low number of $0^{+}$fish caught in November which had significantly higher marginal increment widths (Table 

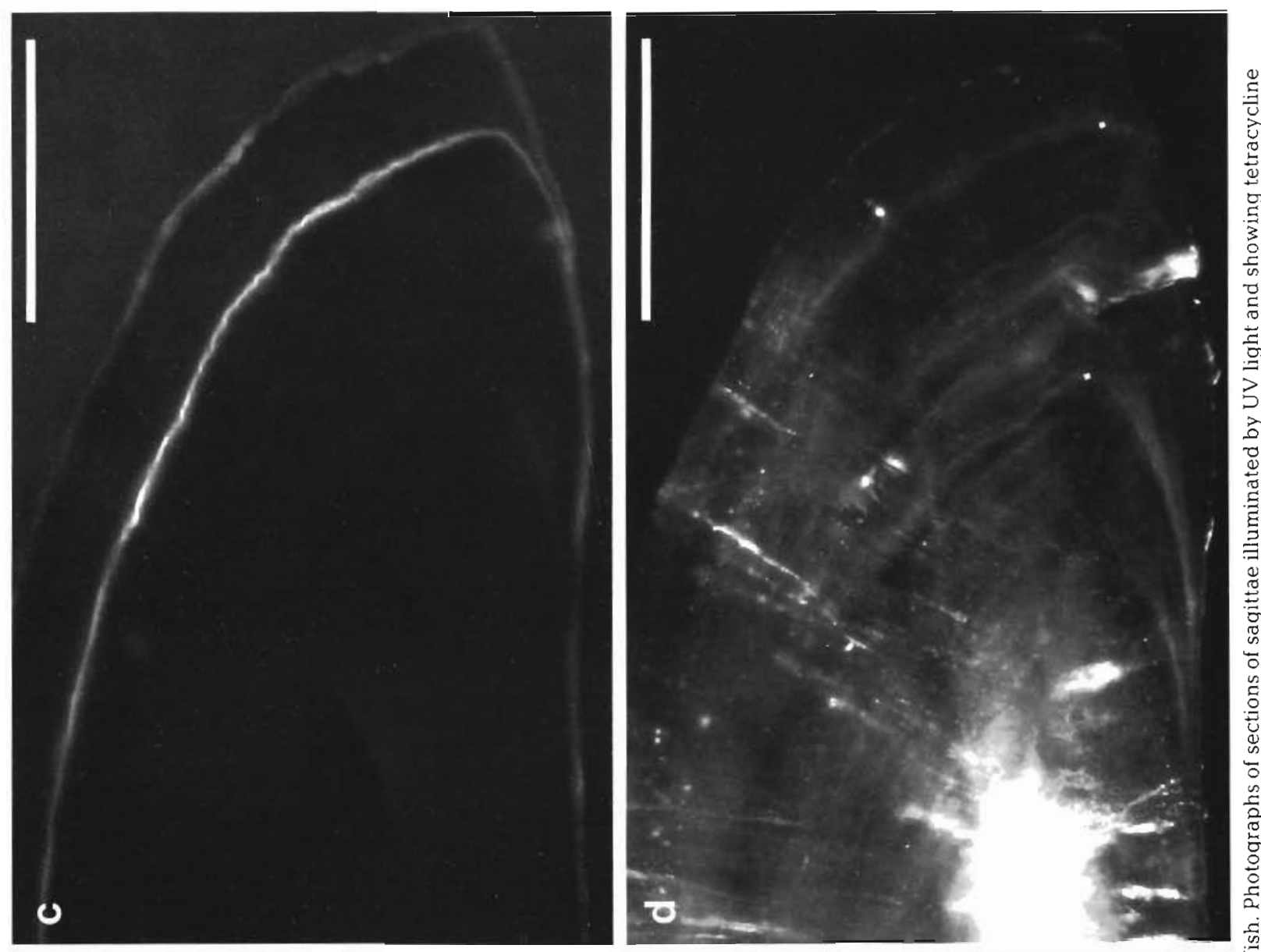

छ 

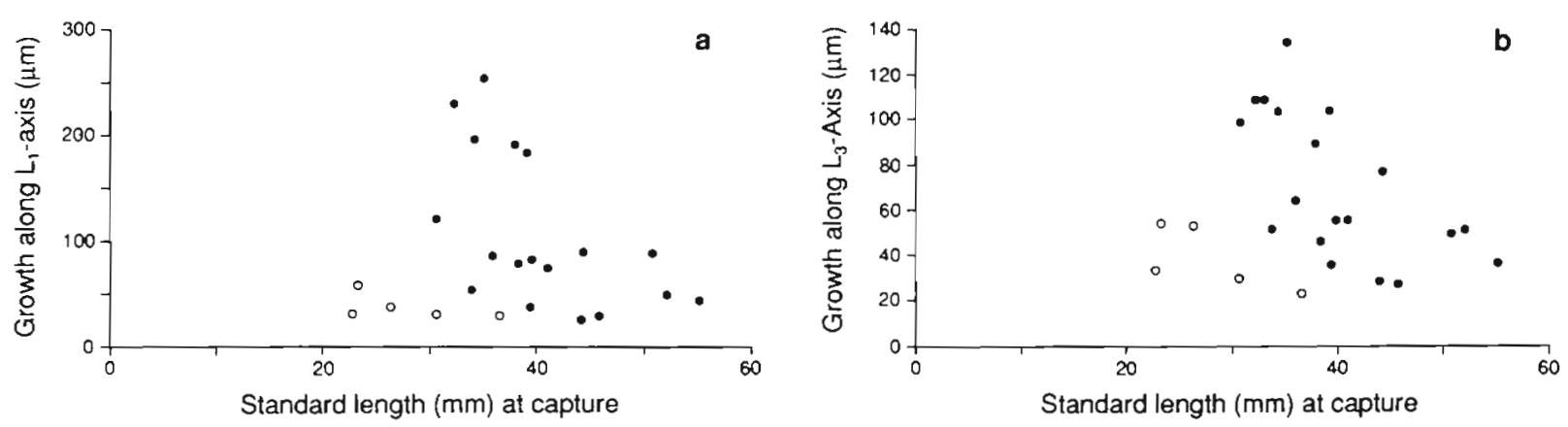

Fig. 6. Pomacentrus mollucensis. (a) L1-axis of section. (b) L3-axis of section. Relationship between amount of growth of the otolith since treatment with tetracycline and SL of the fish at time of capture. (0) Fish captured in September 1988, (•) fish captured in February 1989

Table 2. Pomacentrus mollucensis. Results of analysis of otoliths from fish marked with tetracycline and recaptured. Fish nos. 1 to 5 were recaptured in September 1988 and nos. 6 to 23 in February 1989. Absolute growth refers to distance between tetracycline band and edge of the otolith along the specified axis. Mean width is the distance between last-formed opaque increment and edge of the otolith (measured twice). Comparison refers to the number of increments observed between tetracycline band and edge of otolith

\begin{tabular}{|c|c|c|c|c|c|c|c|c|}
\hline \multirow[t]{2}{*}{ Fish } & \multirow{2}{*}{$\underset{(\mathrm{mm})}{\mathrm{SL}}$} & \multirow{2}{*}{$\begin{array}{l}\text { Increment } \\
\text { count }\end{array}$} & \multicolumn{3}{|c|}{ L1-axis } & \multicolumn{3}{|c|}{ L3-axis } \\
\hline & & & $\begin{array}{c}\text { Absolute } \\
\text { growth }(\mu \mathrm{m})\end{array}$ & $\begin{array}{l}\text { Mean width } \\
\pm \mathrm{SE}(\mu \mathrm{m})\end{array}$ & Comparison & $\begin{array}{c}\text { Absolute } \\
\text { growth }(\mu \mathrm{m})\end{array}$ & $\begin{array}{c}\text { Mean width } \\
\pm S E(\mu \mathrm{m})\end{array}$ & Comparison \\
\hline 1 & 22.7 & 0 & 30 & - & 0 & 33 & - & 0 \\
\hline 2 & 23.2 & 0 & 58 & - & 0 & 54 & - & 0 \\
\hline 3 & 26.3 & 0 & 37 & - & 0 & 53 & - & 0 \\
\hline 4 & 30.6 & 0 & 30 & - & 0 & 30 & - & 0 \\
\hline 5 & 36.5 & 1 & 29 & $188 \pm 0$ & 0 & 23 & $87 \pm 0$ & 0 \\
\hline 6 & 30.5 & 1 & 138 & $33 \pm 0$ & 1 & 100 & $34 \pm 0$ & 1 \\
\hline 7 & 32.1 & 1 & 230 & $94 \pm 2$ & 1 & 109 & $55 \pm 2$ & 1 \\
\hline 8 & 33.8 & 2 & 52 & $36 \pm 1$ & 1 & 52 & $31 \pm 3$ & 1 \\
\hline 9 & 34.2 & 1 & 189 & $70 \pm 1$ & 1 & 99 & $37 \pm 9$ & 1 \\
\hline 10 & 34.9 & 1 & 253 & $109 \pm 7$ & 1 & 135 & $63 \pm 2$ & 1 \\
\hline 11 & 35.9 & 2 & 85 & $61 \pm 3$ & 1 & 64 & $36 \pm 6$ & 1 \\
\hline 12 & 37.8 & 1 & 161 & $96 \pm 6$ & 1 & 101 & $42 \pm 2$ & 1 \\
\hline 13 & 38.2 & 3 & 75 & $47 \pm 1$ & 1 & 48 & $35 \pm 2$ & 1 \\
\hline 14 & 39.1 & 1 & 184 & $105 \pm 3$ & 1 & 104 & $42 \pm 2$ & 1 \\
\hline 15 & 39.4 & 5 & 37 & $23 \pm 1$ & 1 & 36 & $24 \pm 5$ & 1 \\
\hline 16 & 39.6 & 2 & 82 & $59 \pm 4$ & 1 & 55 & $26 \pm 4$ & 1 \\
\hline 17 & 41.0 & 3 & 74 & $46 \pm 5$ & 1 & 55 & $32 \pm 2$ & 1 \\
\hline 18 & 44.0 & 6 & 23 & $18 \pm 1$ & 1 & 29 & $22 \pm 0$ & 1 \\
\hline 19 & 44.3 & 2 & 90 & $67 \pm 3$ & 1 & 77 & $36 \pm 2$ & 1 \\
\hline 20 & 45.7 & 5 & 28 & $21 \pm 2$ & 1 & 28 & $23 \pm 0$ & 1 \\
\hline 21 & 50.7 & 3 & 87 & $56 \pm 7$ & 1 & 49 & $28 \pm 9$ & 1 \\
\hline $\begin{array}{l}21 \\
22\end{array}$ & 52.0 & 3 & 48 & $28 \pm 7$ & 1 & 52 & $23 \pm 0$ & 1 \\
\hline 23 & 55.1 & 5 & 41 & $24 \pm 1$ & 1 & 37 & $24 \pm 6$ & 1 \\
\hline
\end{tabular}

3. Fig. 9). This small number of individuals is likely to be the remnants of the $0^{+}$cohort from the previous summer which had not formed their first increment before their capture in November. The marginal increments for both the $1^{+}$and $2^{+}$age classes, as measured along the L1-axis, were significantly higher in September than November (Table 3). This was also the case for the $1^{+}$age class along the L3 axis (Table 3 ), although there was no significant difference amongst occasions for the $2^{+}$age class. In general, these results suggest that the majority of the $\mathrm{O}^{+}, 1^{+}$and $2^{+}$fish formed their last opaque increment between September and November, although at the time of capture some had not as yet done so. The sample sizes available for the older age classes were too small for statistical comparisons. 

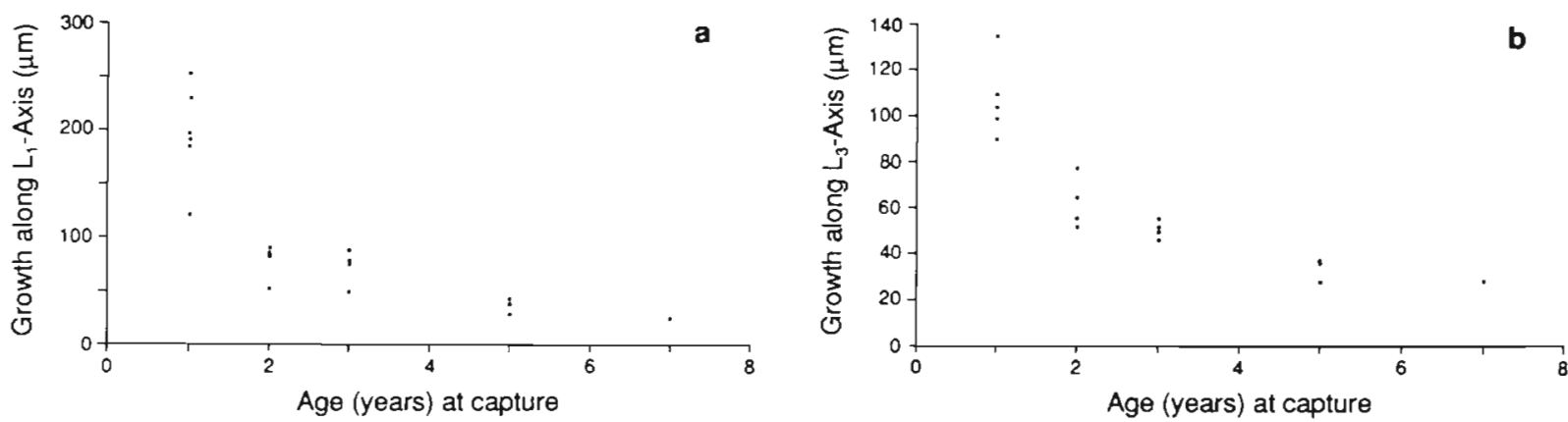

Fig. 7. Pomacentrus mollucensis. (a) L1-axis of section. (b) L3-axis of section. Relationship between absolute growth of the otolith since treatment with tetracycline and age of the fish at the time of capture

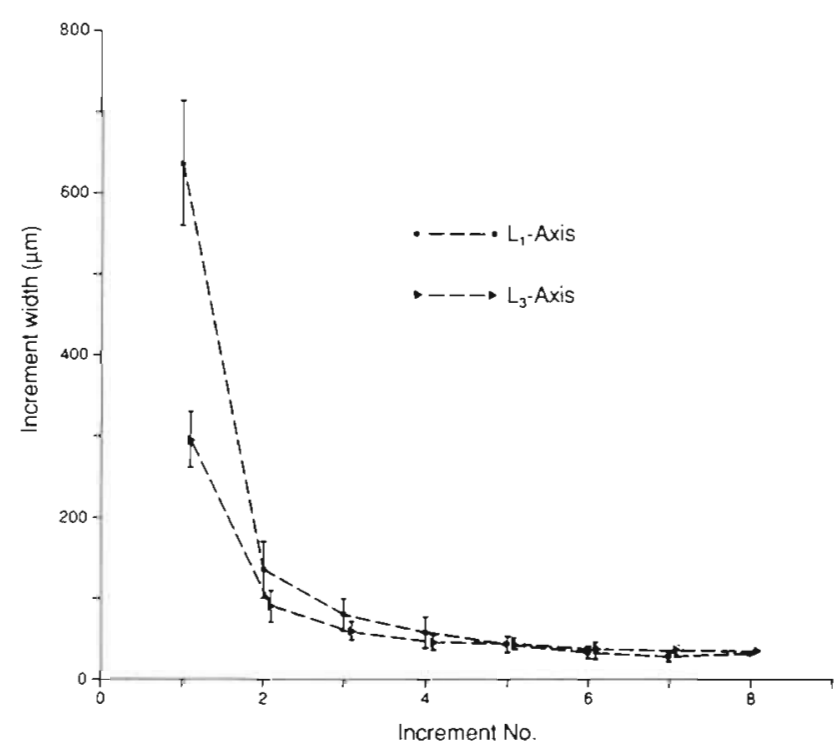

Fig. 8. Pomacentrus mollucensis. Relationship between mean increment width ( \pm SE) and increment number as counted away from the central core for both L1 and L3 axes of the sections

\section{Growth and age-structures}

The sections of 124 otoliths were examined on 2 occasions to assess the precision in the interpretation of their structure. Of these, 8 were considered unreadable on one or both occasions. For the remainder, counts ranged between 0 and 8 , while the differences between counts of the same otolith ranged between 0 and 3 (Table 4 ). For $74.1 \%$ of the otoliths the 2 counts were the same, for $17.2 \%$ they differed by 1 and for $8.6 \%$ they differed by $>1$. Precision of the counts decreased with increasing increment number suggesting that ambiguity was related to the complexity of the otolith structure. The results, however, suggest that it is likely that the otoliths were largely interpreted in the same way on both occasions, but some otoliths were generally less clear and more difficult to interpret than others, which led to the differences between the counts.

For the 30 fish whose 2 counts of the same otolith were different, the second independent estimate of age was used for analysis of growth and age because by this stage more experience had been gained in the interpretation of the structure of these otoliths. The rate of growth of Pomacentrus mollucensis declined exponentially with age (Fig. 10), resulting in curved growth functions for which Von Bertalanffy growth parameters were calculated (Table 5). Given the considerable overlap in the standard errors for each parameter, it is unlikely that there was any major difference amongst these growth functions.

The age structures of populations collected in September and February consisted of relatively large numbers of $0^{+}, 1^{+}$and $2^{+}$fish and smaller numbers of the older age classes up to $8^{+}$(Fig. 11). The November sample is more difficult to interpret because it is around this time that the fish form their new increment and as indicated earlier some had formed this whilst others had not. This sample does however further support the observation that the populations consist mainly of the first few year classes and lower numbers of older fish.

\section{DISCUSSION}

\section{Analysis of otoliths}

For otoliths to be used as an aging tool they must grow through the lives of the fish. For Pomacentrus molucensis length and thickness of the sagittae increased isometrically with $\mathrm{SL}$, but growth around the lateral edges slowed down, indicating asymmetrical growth of the otolith through time, resulting in an ontogenetic change of shape. Initially, the otoliths grew consistently in length, breadth and thickness but later 

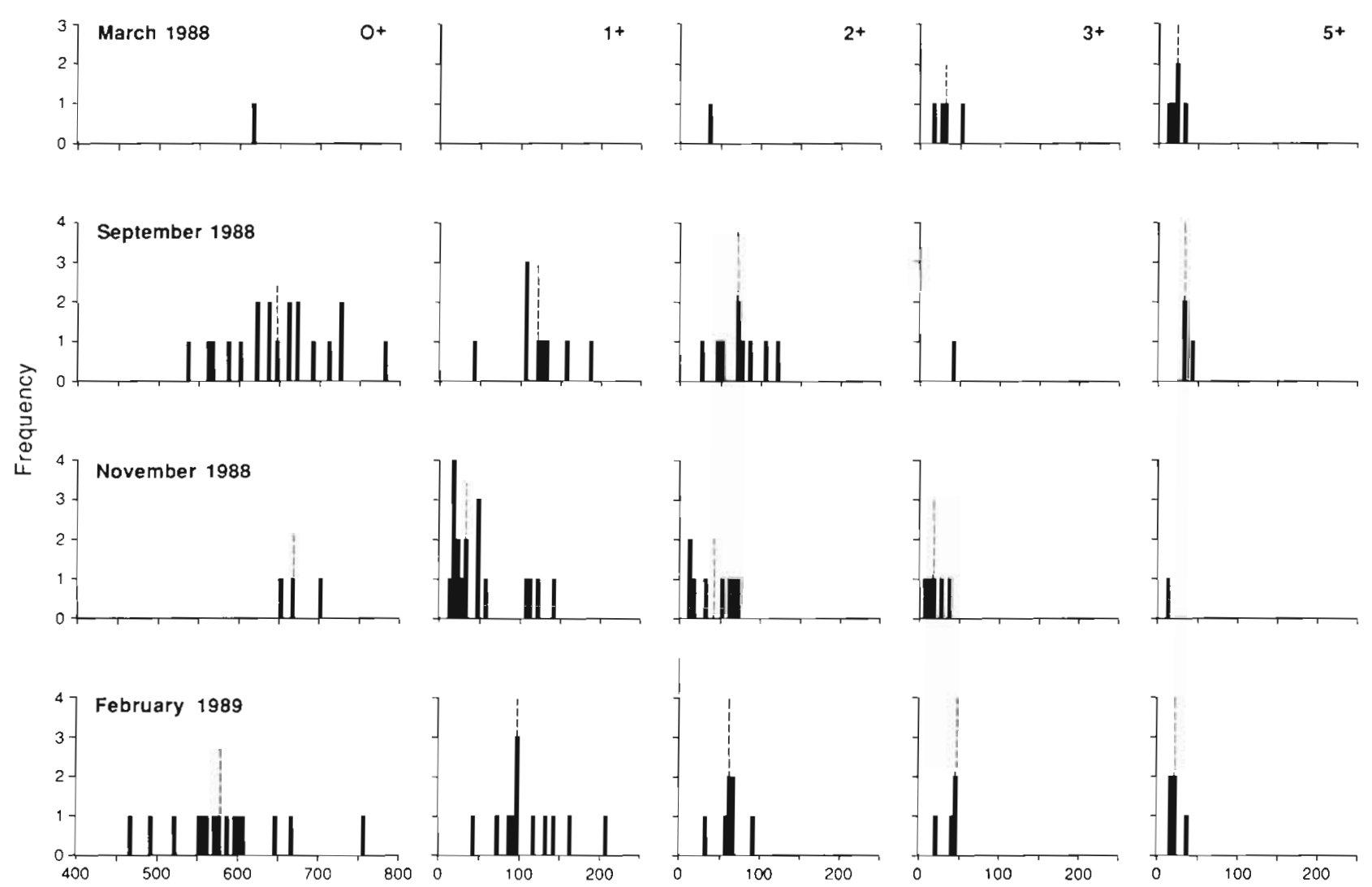

Distance from edge to last increment $(\mu \mathrm{m})$

Fig. 9. Pomacentrus mollucensis. Frequency distribution for number of fish displaying the various widths of marginal increments. The different distributions relate to fish from 5 age classes, from the 4 sampling occasions. Median of each distribution is indicated by a dashed line

Table 3. Pomacentrus mollucensis. Comparison amongst mean marginal increment widths from 3 sampling occasions, as measured along the L1 and L3 axes. Results of SNK tests are indicated by underlining. Sample sizes from which means were calculated are indicated in brackets

\begin{tabular}{|c|c|c|c|}
\hline Age & \multicolumn{3}{|c|}{ Sampling occasion and mean marginal increment width ( $\pm S E$ ) } \\
\hline \multicolumn{4}{|c|}{ L1-axis } \\
\hline $0^{+}$ & $\begin{array}{c}\text { Nov } 1988 \\
673.1 \pm 14.5(3)\end{array}$ & $\begin{array}{c}\text { Sept } 1988 \\
649.7 \pm 14.5(19)\end{array}$ & $\begin{array}{c}\text { Feb } 1989 \\
585.0 \pm 18.4(15)\end{array}$ \\
\hline $1^{+}$ & $\begin{array}{c}\text { Sept } 1988 \\
121.0 \pm 13.2(9)\end{array}$ & $\begin{array}{c}\text { Feb } 1989 \\
113.0 \pm 12.5(12)\end{array}$ & $\begin{array}{c}\text { Nov } 1988 \\
50.2 \pm 9.9(18)\end{array}$ \\
\hline $2^{+}$ & $\begin{array}{c}\text { Sept } 1988 \\
74.3 \pm 10.5(9)\end{array}$ & $\begin{array}{c}\text { Feb } 1989 \\
63.9 \pm 6.0(7)\end{array}$ & $\begin{array}{c}\text { Nov } 1988 \\
41.0 \pm 9.1(8)\end{array}$ \\
\hline \multicolumn{4}{|c|}{ L3-axis } \\
\hline $0^{+}$ & $\begin{array}{c}\text { Nov } 1988 \\
321.8 \pm 8.6(3) \\
\end{array}$ & $\begin{array}{c}\text { Sep } 1988 \\
290.2 \pm 5.6(20)\end{array}$ & $\begin{array}{c}\text { Feb } 1989 \\
242.5 \pm 8.1(15)\end{array}$ \\
\hline $1^{+}$ & $\begin{array}{c}\text { Sep } 1988 \\
70.6 \pm 6.8(9)\end{array}$ & $\begin{array}{c}\text { Feb } 1989 \\
59.6 \pm 5.8(12)\end{array}$ & $\begin{array}{c}\text { Nov } 1988 \\
40.7 \pm 8.2(17)\end{array}$ \\
\hline $2^{+}$ & $\begin{array}{c}\text { Nov } 1988 \\
42.4 \pm 9.7(8)\end{array}$ & $\begin{array}{c}\text { Sept } 1988 \\
41.8 \pm 5.0(7)\end{array}$ & $\begin{array}{c}\text { Feb } 1989 \\
34.1 \pm 1.5(7)\end{array}$ \\
\hline
\end{tabular}


Table 4. Pomacentrus mollucensis. Results of comparison of 2 counts of increments in otolith sections. Difference refers to the deviation of the first count from the second count which is indicated (-ve indicates second count lower than first, +ve indicates first count lower than second). Variation refers to the percentage of otoliths per age class whose counts varied by the amounts indicated

\begin{tabular}{|c|c|c|c|c|c|c|c|c|c|c|c|}
\hline \multirow{2}{*}{$\begin{array}{l}\text { Second } \\
\text { count }\end{array}$} & \multicolumn{6}{|c|}{ Difference } & & \multicolumn{4}{|c|}{ Variation between readings } \\
\hline & -2 & -1 & 0 & 1 & 2 & 3 & Total & 0 & \pm 1 & \pm 2 & \pm 3 \\
\hline 0 & 1 & & 43 & & & & 44 & 97.7 & 2.3 & & \\
\hline 1 & 1 & & 17 & 6 & & & 24 & 70.8 & 25.0 & 4.2 & \\
\hline 2 & & 1 & 9 & 3 & 1 & & 14 & 64.3 & 28.6 & 7.1 & \\
\hline 3 & & 3 & 4 & & 4 & & 11 & 36.4 & 27.3 & 36.4 & \\
\hline 4 & & & 5 & 1 & & & 6 & 83.3 & 16.7 & & \\
\hline 5 & & 1 & 7 & & 1 & & 9 & 77.8 & 11.1 & 11.1 & \\
\hline 6 & & 1 & 1 & 1 & 1 & & 4 & 25.0 & 50.0 & 25.0 & \\
\hline 7 & & 1 & & 1 & & 1 & 3 & & 66.7 & & 33.3 \\
\hline 8 & & & & 1 & & & 1 & & 100.0 & & \\
\hline Total & 2 & 7 & 86 & 13 & 7 & 1 & 116 & & & & \\
\hline$\%$ of total & 1.7 & 6.0 & 74.1 & 11.2 & 6.0 & 0.9 & & & & & \\
\hline
\end{tabular}
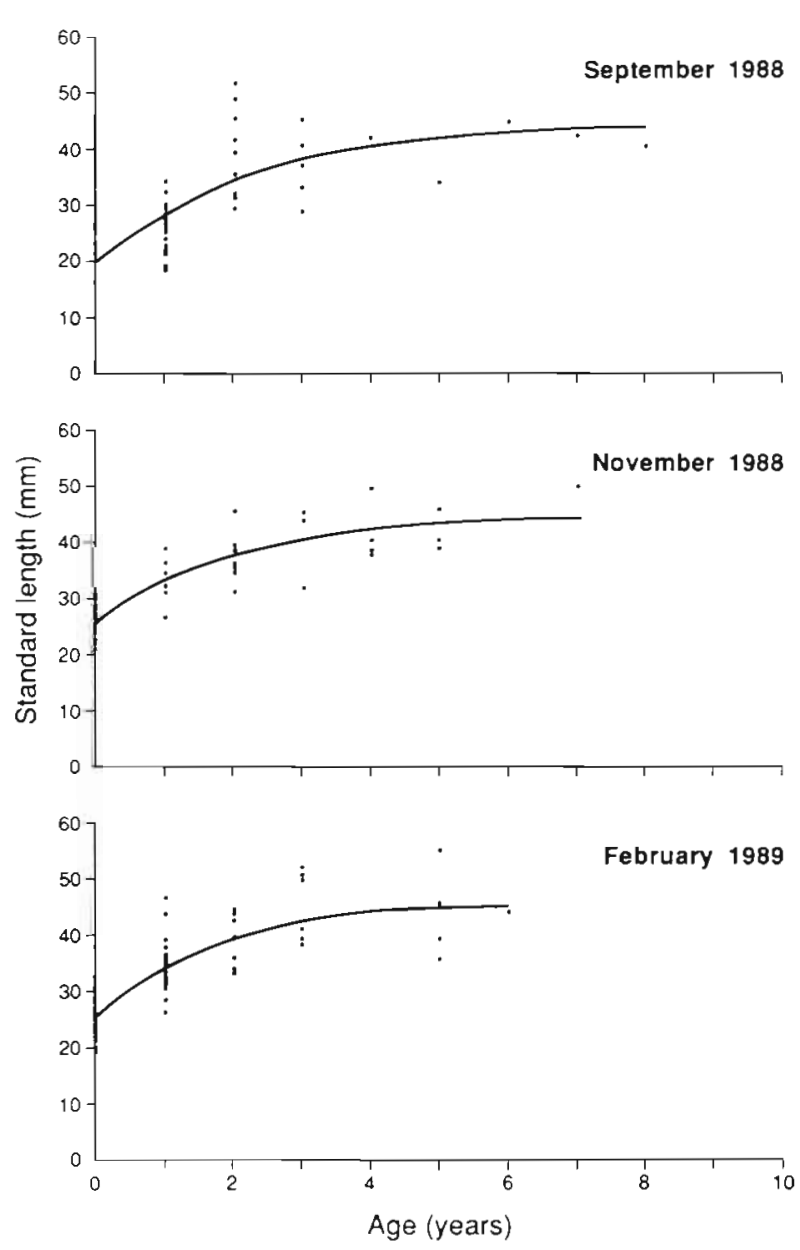

Fig. 10. Pomacentrus mollucensis. Relationship between size and age for the 3 representative samples collected between September 1988 and February 1989. Points are direct estimates of size-at-age and each line represents the calculated Von Bertalanffy growth curve for each sample, the parameters of which are indicated in Table 5
Table 5. Pomacentrus mollucensis. Von Bertalanffy growth parameters ( \pm SE) based on estimates of size-at-age of the 3 representative samples

\begin{tabular}{|lclc|}
\hline $\begin{array}{l}\text { Collection } \\
\text { date }\end{array}$ & $\mathrm{L}_{\infty}$ & $\mathrm{K}$ & $\mathrm{t}_{0}$ \\
\hline Sep 1988 & $45.0 \pm 2.7$ & $0.49 \pm 0.15$ & $-1.74 \pm 0.43$ \\
Nov 1988 & $44.0 \pm 4.4$ & $0.45 \pm 0.19$ & $-1.31 \pm 0.59$ \\
Feb 1989 & $45.6 \pm 2.9$ & $0.6 \pm 0.2$ & $-1.37 \pm 0.37$ \\
\hline
\end{tabular}

new layers were added to the medial surface which thickened the structure whilst the growth in breadth decreased. This maintained the accumulation of otolith mass, at a rate that was not directly proportional to the growth of the fish in either SL or weight. For P. molIucensis the otoliths continued to grow as the fish grew, although the relationships were generally more complex than direct proportionality.

To be useful for aging, otoliths must display an internal structure of increments. In Pomacentrus mollucensis thin sections of otoliths (50 to $100 \mu \mathrm{m}$ ) viewed under reflected white light showed narrow opaque increments alternating with wider translucent increments similar to the pattern described in other tropical and temperate fish (Loubens 1978, Power 1978, Taubert \& Tranquili 1982, Johnson 1983, Hill \& Radtke 1988). The clarity of the increments and the quality of the preparations depended upon the orientation of the sections but also varied amongst individuals. Such variability amongst otoliths is common and in many population studies some otoliths are considered unreadable for various reasons (e.g. Withell \& Wankowski 1988).

The final criterion for the usefulness of otoliths is that the internal structure of increments must form on a regular and determinable time scale. In this study I 

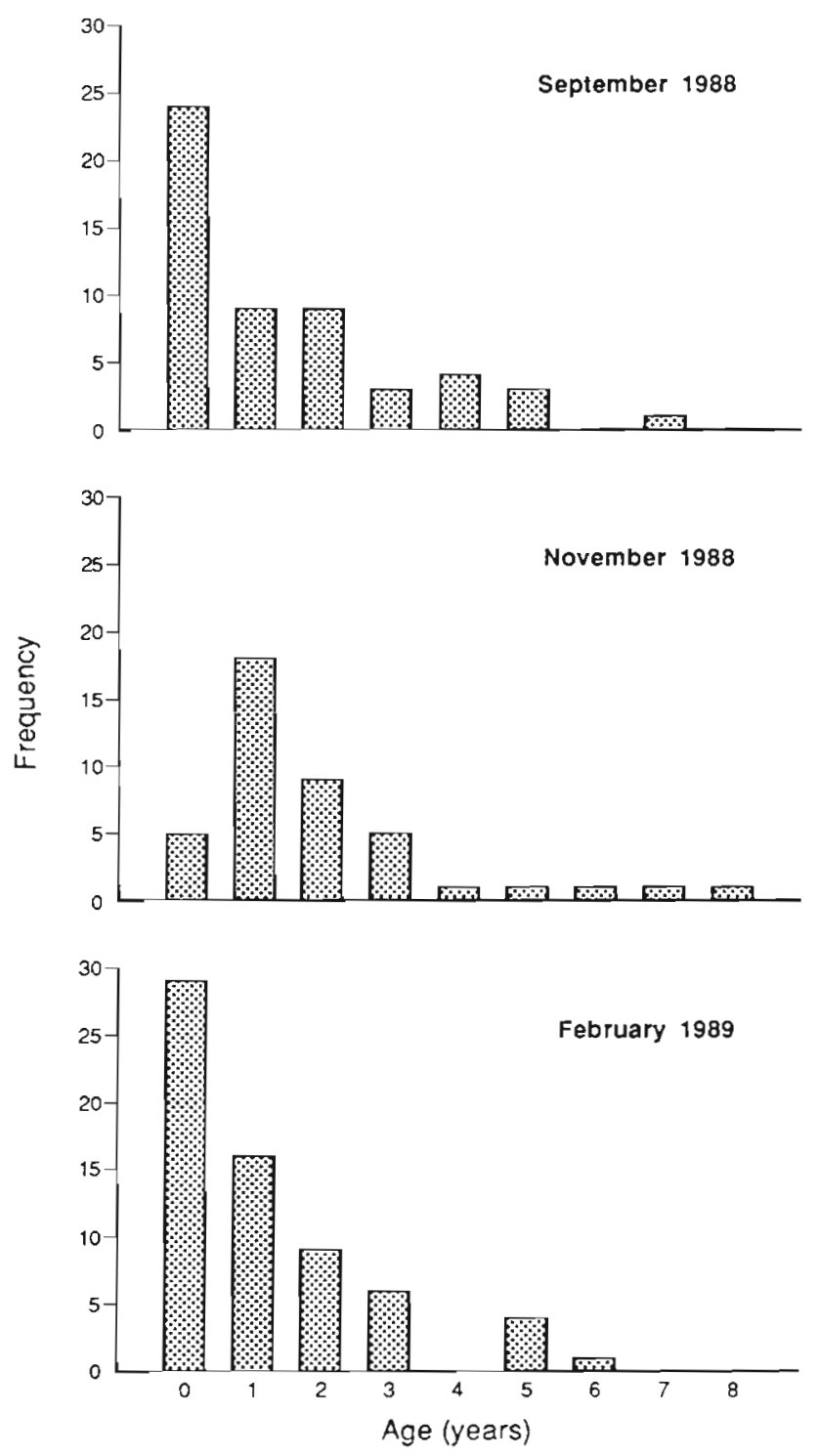

Fig. 11. Pomacentrus mollucensis. Age structures derived for the 3 representative samples collected between September 1988 and February 1989

used 2 independent methods to assess the formation of increments in the otoliths, the results of which complemented each other. The analysis of marginal increments was weakened by the limited number of sampling occasions and the small number of fish available per age class for each occasion. This limited sampling alone was not sufficient to confirm that only one increment was formed annually, as has been achieved by other studies involving marginal increment studies (e.g. Williams \& Bedford 1974). These results did however suggest that for several age classes one opaque increment was produced in the austral spring, similar to that described for other tropical and sub-tropical taxa (Loubens 1978, Johnson 1983). At present, it has not been determined whether these opaque increments are directly related to an accelerating fish metabolism associated with water temperature or food availability, or to a check associated with the onset of the breeding condition.

The best evidence for the period of formation of increments was provided by the analysis of fish marked with tetracycline. When the results of the independent analyses of these otoliths, under transmitted white light (to view incremental structure) and UV light (to view the tetracycline band) were combined, the results indicated that fish of ages of 0 to 6 yr consistently added one new increment to the otolith structure in the period between treatment and capture (335 d). Although the number of tagged fish that were successfully recaptured was small, the unequivocal interpretation of the structure of these otoliths and the consistency amongst individuals strongly supports the hypothesis that the opaque increments were formed on an annual basis.

The above result regarding the formation of yearly increments in the structure of the otoliths of a species of pomacentrid is supported by several recent studies on the microstructure of the otoliths of several other species from this family. For Dascyllus albisella from Hawaii there was a good correspondence between patterns assumed to be deposited daily and annually (Hill \& Radtke 1988), whilst Plectroglyphidodon lacrymatus from New Guinea deposited sufficient microincrements to suggest that fish lived for up to $4 \mathrm{yr}$ (Polunin \& Brothers 1989). So it is likely that tropical reef fish can be aged using the traditional methods used for temperate species. Furthermore, the methodology may have wider applicability than was previously thought as other studies have indicated that growth of tropical reef fish can be seasonal which may therefore be reflected in their otoliths. By mark-recapture studies seasonal growth has been demonstrated for one tetradontid species at Lizard Reef on the northern GBR (Gladston \& Westoby 1988), 3 species of chaetodonts (Fowler 1988) and 2 species of pomacentrids at One Tree Reef on the southern GBR (Doherty 1983, Jones 1987), and 2 species of acanthurids one each at Hawaii and the Virgin Islands (Randall 1961, 1962). Examples of seasonal growth by fish from tropical marine environments other than coral reefs are listed in Longhurst \& Pauly (1987).

It is quite likely that the fish considered in this study had experienced considerable environmental seasonality through their lives. Shallow habitats on reefs of the GBR such as reef flats, crests and lagoons have an annual variation of mean water temperature of up to $10^{\circ} \mathrm{C}$ (Potts \& Swart 1984, Fowler 1988, Gladstone \& Westoby 1988) with the seasonal range of temperature being similar at both the northern and southern ends of the GBR, although the thermal regime shifts upwards 
with decreasing latitude. Since John Brewer reef lies in the central GBR it is likely that shallow habitats, such as the lagoon from where the specimens were taken, also experience such annual temperature ranges. This is well in excess of the 4 to $5^{\circ} \mathrm{C}$ range that has been suggested as necessary to induce the production of seasonal increments (Longhurst \& Pauly 1987).

The reef slope habitats on Heron Reef $\left(23^{\circ} 26^{\prime} \mathrm{S}, 151^{\circ}\right.$ $\left.55^{\prime} \mathrm{E}\right)$ on the southern GBR showed a mean temperature variation of only $6^{\circ} \mathrm{C}$ over the extensive period of August 1974 to November 1976 (Potts \& Swart 1984). This temperature range is low because variation in this habitat is largely ameliorated by the influence of oceanic waters. If as indicated above a temperature range of 4 to $5^{\circ} \mathrm{C}$ is necessary to induce increment formation in otoliths then fish that occupy the reef slope may rarely or never produce annuli. These differences in thermal regime among habitats suggest that some fish may form annuli and can be successfully aged whereas others may not, even though they occupy the same reef and are separated by only several hundred metres.

\section{Growth and age structures}

Since growth in SL of Pomacentrus mollucensis decreased exponentially with age, which is characteristic for fish (Jones 1976), growth was described by the Von Bertalanffy equation. These calculations suggest that this species achieves up to $75 \%$ of $\mathrm{L}_{\infty}$ in the first year and up to $87 \%$ in the second. Such growth is fast but not atypical for small, tropical species which characteristically grow to $>50 \%$ of $\mathrm{L}_{\infty}$ in the first year (Buesa 1987). In contrast, larger species (i.e. $\mathrm{L}_{\infty}>50 \mathrm{~cm}$ ) generally have lower $\mathrm{K}$ values and grow to $<50 \%$ of $\mathrm{L}_{\infty}$ in their first year. Despite this fast growth of $P$. molIucensis it was relatively slower than that of other species of pomacentrids, determined using other techniques (summarised by Munro \& Williams 1985). In particular, the growth of Chromis ternatensis from the Gulf of Aqaba (Red Sea) with values of $\mathrm{K}$ between 2 and 4 was exceptionally fast whilst those rates of Stegastes planifrons and $S$. nigricans from Jamaica (Caribbean) and Moorea (Pacific) respectively, were more similar to, but still higher than those of $P$. mollucensis.

There was considerable variability in the size-at-age of Pomacentrus mollucensis. Given that the fish considered in the 3 samples collected in September, November and February 1989 came from separate subpopulations, it is difficult to relate any within-sample variability to environmental variables as these would need to work at a scale of less than the size of the coral head. Therefore, between-habitat differences in growth such as described by Ralston (1981) are unlikely to be relevant at this smaller scale. Rather, differences in growth pattern are most likely to have been determined genetically and socially. In many taxa of fish there are sex-based differences in growth characteristics (Six \& Horton 1976, Kimura et al. 1979, Johnson \& Saloman 1984, Fable et al. 1987, Fujiwara \& Hankin 1988) whilst pomacentrids are also known to demonstrate intraspecific density-dependent growth (Doherty 1982, 1983, Jones 1987). The natural variation in size-at-age demonstrated in this study may be the consequence of such influences under regimes of varying population sizes.

In conclusion, this study has shown that juveniles and adults of a small, common coral reef fish form increments in their otoliths on an annual basis, which can be used to age individual fish. The potential now exists for age-structured demographic studies and to answer previously untestable ecological hypotheses. Further species should be studied in this way to determine the generality of increment formation and to test hypotheses about whether such are environmentally determined (in which case they should be synchronous amongst species) or breeding checks (should show differences in the timing of formation).

Acknowledgements. The field work was greatly assisted by M. Cappo and the crew of the RV 'Lady Basten'. Comments by P. Doherty, J. Lough and D. Williams and 3 anonymous referees improved earlier drafts of this paper. The study was financed by an Australian Marine Science and Technologies grant (no. A08700728) with logistic support from the Australian Institute of Marine Science. This is AIMS contribution no. 494.

\section{LITERATURE CITED}

Bagenal, T B. (ed.) (1974). The ageing of fish. Proceedings of an International Symposium. Unwin Brothers Ltd, Old Woking

Beamish, R. J. (1979a). Differences in the age of Pacific Hake (Merluccius productus) using whole otoliths and sections of otoliths. J. Fish. Res. Bd Can. 36: 141-151

Beamish, R. J. (1979b). New information on the longevity of Pacific Ocean Perch (Sebastes alutus). J. Fish. Res. Bd Can. 36: $1395-1400$

Brothers, E. B. (1982). Aging reef fishes. NOAA natn. mar. Fish. Serv., Tech. Memo., U.S. Dept. Commerce NMFSSEFC-80: $3-23$

Buesa, R. J. (1987). Growth rate of tropical demersal fishes. Mar. Ecol. Prog. Ser. 36: 191-199

Campana, S. E. (1984). Comparison of age determination methods for the starry flounder. Trans. Am. Fish. Soc. 113: 365-369

Doherty, P. J. (1982). Some effects of density on the juveniles of two species of tropical, territorial damselfish. J. exp. mar. Biol. Ecol. 65: 249-261

Doherty, P. J. (1983). Tropical territorial damselfishes: is density limited by aggression or recruitment? Ecology 64 $176-190$ 
Fable, W A., Johnson, A. G., Barger, L. E. (1987). Age and growth of Spanish mackerel, Scomberomorus maculatus, from Florida and the Gulf of Mexico. Fish. Bull. U.S. 85: $777-783$

Fowler, A. J. (1988). Aspects of the population ecology of three species of chaetodonts at One Tree Reef, southern Great Barrier Reef. Ph. D. thesis, University of Sydney

Fowler, A. J. (1989). Description, interpretation and use of the microstructure of otoliths from juvenile butterflyfishes (family Chaetodontidae). Mar. Biol, 102: 167-181

Fujiwara, S., Hankin, D. G. (1988). Aging discrepancy related to asymmetrical otolith growth for sablefish Anoplopoma fimbria in northern California. Nippon Suisan Gakkaishi 54: $27-31$

Gladstone, W., Westoby, M. (1988). Growth and reproduction in Canthigaster valentini (Pisces, Tetradontidae): a comparison of a toxic reef fish with other reef fishes. Environ. Biol. Fish. 21: 207-223

Hill, K. T., Radtke, R. L. (1988). Gerontological studies of the damselfish, Dascyllus albisella. Bull. mar. Sci. 42 (3): $424-434$

Johnson, A. G. (1983). Age and growth of yellowtail snapper from South Florida. Trans. Am. Fish. Soc. 112: 173-177

Johnson, A. G., Saloman, C. H. (1984). Age, growth and mortality of gray triggerfish, Balistes capriscus from the northeastern Gulf of Mexico. Fish. Bull. U.S. 82: 485-492

Jones, R. (1976). Growth of fishes. In: Cushing, D. H., Walsh, J. J. (eds.) The ecology of the seas. Blackwell Scientific Publications, Oxford, p. 251-279

Jones, G. P. (1987). Competitive interactions among adults and juveniles in a coral reef fish. Ecology 68: 1534-1547

Kimura, D. K., Mandapat, R. R., Oxford, S. L. (1979). Method, validity and variability in the age determination of yellowtail rockfish (Sebastes flavidus), using otoliths. J. Fish. Res. Bd Can. 36: 377-383

Kobayashi, S., Yuki, R., Furui, T., Kosugiyama, T (1964). Calcification in fish and shell-fish - I. Tetracycline labelling pattems on scale, centrum and otolith in young goldfish. Bull. Jap. Soc. Scient. Fish. 30: 6-13

Longhurst, A. R., Pauly, D. (1987). Ecology of tropical oceans. Academic Press Inc., London

Loubens, G. (1978). Biologie de quelque especes de poisson du lagon Neo-Caledonien. I. Determination de l'age (otolithometrie). Cah. ORSTOM Oceanogr. XVI: 263-283

Manooch, C. S. III (1982). Aging reef fishes in the Southeast Fisheries Centre. NOAA natn. mar Fish. Serv., Tech. Memo., U.S. Dept. Commerce NMFS-SEFC-80: 24-43

Manooch, C. S. III (1987). Age and growth of snapper and groupers. In: Polovina, J. J., Ralston, S. (eds.) Tropical snappers and groupers. Biology and fisheries management. Westview Press, Boulder, p. 329-373

McFarlane, G. A., Beamish, R. J. (1987). Selection of dosages of oxytetracycline for age validation studies. Can. J. Fish. Aquat. Sci. 44: 905-909

McPherson, G., Squire, L., O'Brien, J. (1988). Demersal reef fish project 1984-85. Age and growth of four important reef fish species. Report to Great Barrier Reef Marine Park Authority, Townsville, Qld

Munro, J. L., Williams, D. McB. (1985). Assessment and management of coral reef fisheries: biological, environmental

This article was presented by Dr P. W. Sammarco, Canberra, Australia and socio-economic aspects. Proc. 5th Int. Coral Reef Congress, Tahiti 4: 544-581

Odense, P. H., Logan, V. H. (1974). Marking Atlantic salmon (Salmo salar) with oxytetracycline. J. Fish. Res. Bd Can. 31. 348-350

Pannella, G. (1980). Growth patterns in fish sagittae. In: Rhoads, D. C., Lutz, R. A. (eds.) Skeletal growth of aquatic organisms: biological records of environmental change. Plenum Press, New York, p. 519-560

Pentilla, J., Dery, L. M. (eds.) (1988). Age determination methods for Northwest Atlantic species. NOAA Tech. Rep. NMFS72, U. S. Dep. Commerce, Washington, p. 1-135

Pitcher, C. R. (1988). Validation of a technique for reconstructing daily patterns in the recruitment of coral reef damselfish. Coral Reefs 7: 105-111

Poinsard, F., Troadec, J. (1966). Determination de l'age par la lecture des otolithes chez deux especes de Sciaenides Ouest-Africains. (Pseudolithes senegalensis C. V. et. Pseudolithes typus Blkr). J. Cons. perm. int. Explor. Mer 30: 291-307

Polunin, N. V. C., Brothers, E. B. (1989). Low efficiency of dietary carbon and nitrogen conversion to growth in a herbivorous coral reef fish in the wild. J Fish. Biol. 35: 869-879

Potts, D. C., Swart, P. K. (1984). Water temperature as an indicator of environmental variability on a coral reef. Limnol. Oceanogr. 29: 504-516

Power, G. (1978). Fish population structure in Arctic lakes. J. Fish. Res. Bd Can. 35: 53-59

Ralston, S. (1981). Aspects of the reproductive biology and feeding ecology of Chaetodon miliaris, an Hawaiian endemic butterflyfish. Environ. Biol. Fish. 6: 167-176

Randall, J. E. (1961). A contribution to the biology of the convict surgeonfish of the Hawaiian islands, Acanthurus triostegus sandvicensis. Pacif. Sci. 15: 215-272

Randall, J. E. (1962). Tagging reef fishes in the Virgin Islands. Proc. Gulf Caribb. Fish. Inst. 14: 201-241

Ricker, W. E. (1979). Growth rates and models. In: Hoar, W. S., Randall, D. J., Brett, J. R. (eds.). Fish physiology, Vol. VIII. Academic Press, New York, p. 677-742

Six, L. D., Horton, H. F. (1976). Analysis of age determination methods for yellowtail rockfish, canary rockfish and black rockfish off Oregon. Fish. Bull. U. S. 75: 405-414

Taubert, B. D., Tranquili, J. A. (1982). Verification of the formation of annuli in otoliths in largemouth bass. Trans. Am. Fish. Soc. 111. 531-534

Victor, B. C. (1983). Settlement and larval metamorphosis produce distinct marks on the otoliths of the slippery dick. Halichoeres bivittatus. In: Reaka, M. L. (ed.) The ecology of deep and shallow coral reefs. Office of undersea research, U. S. Dept. of Commerce, Washington D. C., p. $47-52$

Williams, T., Bedford, B. C. (1974). The use of otoliths for age determination. In: Bagenal, I B. (ed.) The ageing of fish. Proceedings of an International Symposium. Unwin Brothers, Old Woking, p. 114-123

Withell, A. F., Wankowski, J. W. (1988). Estimates of age an growth of ocean perch, Helicolenus percoides Richardson, in south-eastern Australian waters. Aust. J. mar. Freshwat. Res. 39: 441-459

Manuscript first received: September 19, 1989

Revised version accepted: March 20, 1990 